\title{
Corrosion Behavior of Construction Materials for Intermediate Temperature Steam Electrolysers
}

Nikiforov, Aleksey; Petrushina, Irina; Jensen, Jens Oluf; Bjerrum, Niels

Published in:

ECS Meeting Abstracts

Publication date:

2012

Link back to DTU Orbit

Citation (APA):

Nikiforov, A., Petrushina, I., Jensen, J. O., \& Bjerrum, N. (2012). Corrosion Behavior of Construction Materials for Intermediate Temperature Steam Electrolysers. In ECS Meeting Abstracts The Electrochemical Society. http://ma.ecsdl.org/site/archive/MA2012-02.xhtml

\section{General rights}

Copyright and moral rights for the publications made accessible in the public portal are retained by the authors and/or other copyright owners and it is a condition of accessing publications that users recognise and abide by the legal requirements associated with these rights.

- Users may download and print one copy of any publication from the public portal for the purpose of private study or research.

- You may not further distribute the material or use it for any profit-making activity or commercial gain

- You may freely distribute the URL identifying the publication in the public portal

If you believe that this document breaches copyright please contact us providing details, and we will remove access to the work immediately and investigate your claim 
Corrosion behavior of construction materials for intermediate temperature steam electrolysers Aleksey V. Nikiforov, Irina M. Petrushina, Jens Oluf Jensen, Niels J. Bjerrum

Department of Energy Conversion and Storage, Technical University of Denmark

Kemitorvet 207, DK-2800 Kgs. Lyngby, Denmark

Electrolysis of water is an important process in the long term visions about the use of hydrogen as an energy carrier ${ }^{1}$.

Electrolytes, operating at temperatures above $100{ }^{\circ} \mathrm{C}$ under low humidification are expected to overcome several problems, met in low temperature systems ${ }^{2}$. Among those challenges are water management and necessity to use noble electrocatalysts to catalyze the electrode reactions at lower temperatures. Therefore, considerable efforts have been made recently to develop such materials.

The electrochemical behavior of different construction materials was studied in molten $\mathrm{KHSO}_{4}$ and $\mathrm{KHSO}_{4}-\mathrm{CsH}_{2} \mathrm{PO}_{4}$ electrolytes in air atmosphere. Different grades of stainless steel, nickel-based alloys, as well, as platinum, gold and tantalum electrodes were tested at elevated temperatures.

Several types of commercially available stainless steels and nickel-based alloys were evaluated as possible construction materials. Their corrosion resistance was measured under simulated conditions corresponding to those in intermediate temperature steam electrolysers, using proton conducting solid electrolytes.

Steady-state voltammetry was used to detect the corrosion rates and the corrosion potentials of the selected materials ${ }^{3}$.

It was shown that stainless steels were the least resistant to corrosion under the anodic polarization. Platinum and CVD-coated stainless steel showed superior resistance to corrosion in the selected media.

The electrochemical evaluation of selected materials was performed in the cell, presented in Fig.1.

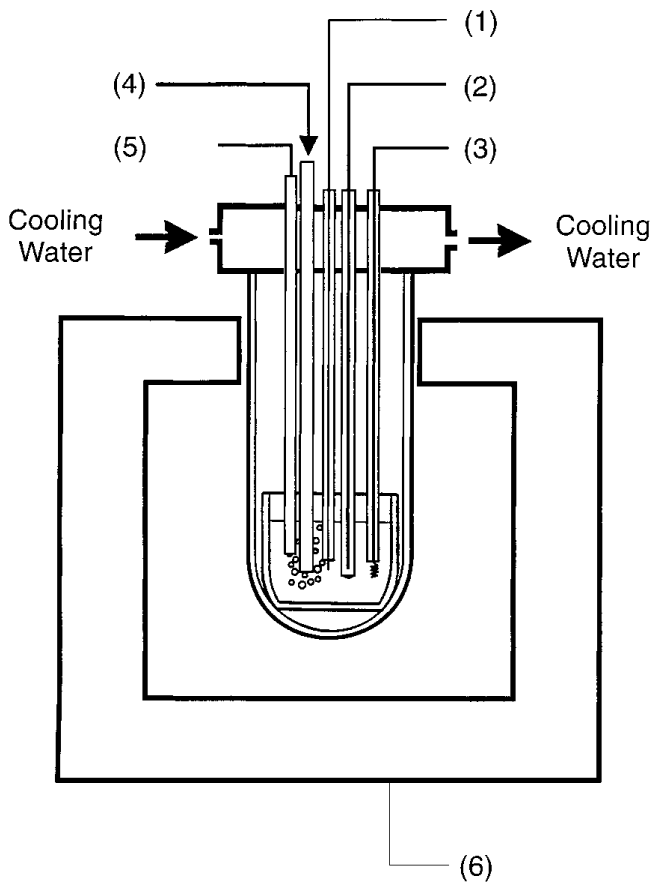

Fig. 1. Electrochemical cell: (1) working electrode; (2) reference electrode; (3) counter electrode; (4) gas inlet; (5) thermocouple, (6) furnace

References:

${ }^{1} \varnothing$. Ulleberg, T. Nakken, A. Eté, Int. J. Hydrogen Energy, 35(2010): 1841-1852.

${ }^{2}$ H.Muroyama, K. Katsukawa, T. Matsui, K. Eguchi, Journal of The Electrochemical Society, 158(9) B1072B1075 (2011).

${ }^{3}$ A.V. Nikiforov, I.M. Petrushina, E. Christensen, A.L. Tomás-García, N.J. Bjerrum, Int. J. Hydrogen Energy, 36 (2011): 111-119. 